\title{
KONSEP DAN STRUKTUR PENGEMBANGAN KURIKULUM SD/MI
}

\author{
Sukati
}

(Dosen PGMI STIA Alma Ata Yogyakarta)

\begin{abstract}
The curriculum is an important instrument of education, because the curriculum is a guide in carrying out instruction which is conducted by teachers, principals or policy makers at higher levels. Along with the developed era which is marked by global of information and technology currenly, the managemant and curriculum development should be done at all levels including in primary education / Islamic primary education levels.

In curriculum development, involving the various components or elements. Each component requires a proper and serious development, because of the unity, connectedness, and coherence between the various components of the curriculum is process for achieving educational goals.
\end{abstract}

Key words: Curriculum development, various component

\section{Pendahuluan}

Salah satu komponen yang penting dalam pendidikan adalah kurikulum, karena kurikulum merupakan komponen pendidikan yang dijadikan acuan oleh setiap satuan pendidikan, baik oleh pengelola maupun penyelenggara; khususnya oleh guru dan kepala sekolah. Oleh karena itu, sejak bangsa Indonesia memiliki kebebasan dalam menyelenggarakan pendidikan sejak saat itu pulalah bangsa Indonesia mengembangkan kurikulumnya sendiri. Dalam hal ini pemerintah telah menyusun kurikulum secara sentralistik untuk diberlakukan kepada seluruh anak bangsa di seluruh Indonesia. Namun kurikulum bersifat dinamis, karena selalu ada penyempurnaan-penyempurnaan secara periodik sesuai dengan faktor-faktor yang mempengaruhinya, misalnya faktor lembaga pendidikan, kajian keilmuan, faktor masyarakat, sistem nilai, situasi dan kondisi,dan sebagainya. 
Penyempurnaan juga dilakukan terhadap struktur kurikulum yang meliputi jumlah mata pelajaran, beban belajar, alokasi waktu, mata pelajaran pilihan dan muatan lokal, serta sistem pelaksanaannya, baik system paket maupun system satuan kredit semester (SKS). Penyempurnaan kurikulum 1994 telah dimulai sejak tahun 2001 dan perintisan dilakukan pada beberapa sekolah oleh pusat kurikulum Balitbang dan Direkrorat Jenderal Dikdas. Draft kurikulum hasil rintisan tersebut semula akan diberlakukan di sekolah-sekolah tahun ajaran 2004/2005; namun dengan lahirnya Undang-undang nomor 20 tahun 2003 tentang sisdiknas dan PP nomor 19 tahun 2005 tentang Standar Nasional Pendidikan, draft tersebut perlu disesuaikan kembali. Sesuai dengan PP tersebut, penyempurnaan kurikulum selanjutnya dilakukan oleh Badan Standar Nasional Pendidikan (BSNP). Penyempurnaan dilakukan berdasarkan hasil kajian para pakar pendidikan yang tergabung di BSNP dan masukan dari masyarakat yang fokusnya pada 2 hal, yaitu pengurangan beban belajar kurang lebih $10 \%$ dan penyederhanaan kerangka dasar dan struktur kurikulum. Penyempurnaan tersebut mencakup singkronisasi kompetensi untuk setiap mata pelajaran antar jenjang pendidikan, beban belajar dan jumlah mata pelajaran serta validasi empirik terhadap standar kompetensi dan kompetensi dasar.

Makalah ini hanya akan difokuskan pada masalah konsep dan struktur pengembangan kurikulum di SD/MI.

\section{Pembahasan}

\section{A. Konsep pengembangan kurikulum}

Dalam setiap pendidikan formal, kurikulum adalah bagian penting. Karena kegiatan utama pendidikan adalah dalam rangka melaksanakan kurikulum yang telah ditetapkan. Kurikulum disini berfungsi untuk menjabarkan idealisme, cita-cita pendidikan, ke dalam langkah-langkah nyata yang akan menjadi pedoman untuk melaksanakan proses pendidikan dan pengajaran. Karena kurikulum bukanlah suatu yang statis, maka kurikulum harus selalu dikembangkan yang berarti dalam pengembangan itu terdapat penyempurnaan-penyempurnaan.

Secara etimologis, kurikulum berasal dari bahasa yunani yaitu curir yang berarti pelari dan curere yang artinya tempat berpacu. Dengan demikian kurikulum berasal dari dunia olah raga pada zaman romawi kuno di yunani, yang mengandung pengertian jarak 
yang harus ditempuh oleh pelari dari garis start sampai garis finish. Selanjutnya istilah kurikulum ini digunakan dalam dunia pendidikan dan mengalami perubahan makna sesuai dengan perkembangan dan dinamika yang ada dalam dunia pendidikan. Secara garis besar, kurikulum dapat diartikan dengan seperangkat materi pendidikan dan pengajaran yang diberikan kepada murid sesuai dengan tujuan pendidikan yang akan dicapai.

Dalam bahasa Arab, kurikulum diterjemahkan menjadi manbaj atau jalan yang terang atau jalan terang yang dilalui oleh manusia pada berbagai bidang kehidupannya. Jadi kurikulum dalam pendidikan Islam menurut Oemar M. al Toumy al-Syaibany adalah suatu jalan terang yang dilalui oleh pendidik terhadap anak didik untuk mengembangkan ketrampilan pengetahuan, dan sikap mereka. Konsep ini dirasa sangat sempit namun terus berjalan sampai pertengahan abad ke-19 sampai akhirnya muncul konsepkonsep pendidikan modern termasuk didalamnya adalah konsep kurikulum. Disini makna kurikulum menjadi sangat luas, ini terlihat dari konsep yang telah dikemukan oleh Hasan Langgulung bahwa kurikulum merupakan sejumlah pengalaman pendidikan, kebudayaan, sosial, olah raga, dan kesenian yang disediakan oleh sekolah untuk anak didiknya baik di dalam maupun luar sekolah dengan maksud membantu anak agar berkembang secara menyeluruh dalam semua aspeknya dan mengubah tingkah laku mereka sesuai dengan tujuan-tujuan pendidikan.

Kurikulum dalam pendidikan Islam termasuk di Madrasah Ibtidaiyah mengandung makna suatu rangkaian program yang mengarahkan kegiatan belajar mengajar yang terencana dengan sistematis dan mengarah pada tujuan serata menggambarkan citacita Islam. Kurikulum pendidikan Islam berisi materi untuk pendidikan seumur hidup/long life education, dan materi pokoknya adalah bahan-bahan, aktifitas dan pengalaman yang mengandung unsur ketauhidan. Dari pemahaman mengenai kurikulum tersebut, maka dapat dideskripsikan secara spesifik yaitu:

- Kurikulum rnerupakan rencana/maksud.

- Kurikulum merupakan rencana kegiatan dan bukan aktifitas.

- Kurikulum berisi berbagai maksud.

- Kurikulum meliputi maksud-maksud formal.

- Kurikulum merupakan suatu sistem. 
- Latihan dan pendidikan keduanya menunjukkan kepada batasannya masing-masing untuk menghindari kesalahan pengertian yang terjadi, apabila salah satu hal tersebut dikemukakan.

- Kurikulum rnemiliki prediksi dan jangkauan ke depan.

\section{B. Struktur Pengembangan Kurikulum}

Pengembangan kurikulum merupakan suatu yang sangat komplek. Kompleksitasnya antara lain disebabkan karena kurikulum memerlukan berbagai asas. Setiap asas sudah merupakan suatu yang rumit, apalagi jika dikaitkan dengan asas yang lain. Selain itu kurikulum juga terdiri dari berbagai komponen utama yang saling berkaitan sehingga membentuk suatu struktur. Dan juga terdapat berbagai definisi yang beragam tentang kurikulum, dimana setiap ahli memiliki rumusan yang berbedabeda tentang kurikulum.

Pengembangan kurikulum pada hakekatnya adalah pengembangan komponen-komponen kurikulum, yang membentuk sistem kurikulum itu sendiri, yakni komponen: tujuan, bahan, metode, peserta didik, pendidik media, lingkungan, sumber belajar, dan lain-lain. Pengembangan terhadap komponenkomponen tersebut adalah supaya tujuan pendidikan dapat dicapai sebagaimana mestinya. Paling tidak ada dua jenis tujuan yang terkandung dalam suatu kurikulum sekolah,yaitu:

1. Tujuan yang ingin dicapai secara keseluruhan oleh setiap institusi pendidikan/tujuan institusional.

2. Tujuan yang ingin dicapai pada setiap bidang studi.

Dari serangkaian tujuan pendidikan yang bersifat hirarkis dan sistemis (Tujuan Pendidikan Nasional, Tujuan Institusional, Tujuan Kurikuler, dan Tujuan Instruksional), hanya tujuan kurikuler dan tujuan institusional yang cenderung mengalami pengembangan-pengembangan yang mengikuti perubahan kurikulum. Namun, pengembangan komponen tujuan dalam pengembangan kurikulum memiliki keterkaitan erat dengan komponen lainnya. Maksudnya, tujuan yang berbeda akan membutuhkan bahan yang berbeda, alat evaluasi yang berbeda, dan sebagainya. Kalau dipahami lebih mendalam mengenai komponenkomponen tersebut, maka masalah pengembangan kurikulum ini merupakan masalah yang amat komplek. Karena tiap komponen 
memiliki kerumitan yang khas, dan akan lebih komplek lagi jika harus dihubungkan dengan komponen-komponen lain secara fungsional, baik komponen tujuan, isi/bahan/materi, media, stategi, proses belajar mengajar dan membuat evaluasi. Berikut akan diuraikan secara singkat masing-masing komponen kurikulum:

1. Komponen Tujuan

Tujuan merupakan hal yang penting dalam proses pendidikan.Tujuan yang ingin dicapai meliputi aspek kognitif, afektif dan psikomotor. Aspek kognitif diarahkan pada pengembangan akal, intelektual anak didik, aspek afektif diarahkan pada pengembangan rohani anak, sedangkan aspek psikomotor diarahkan pada pengembangan keterampilan jasmani anak didik. Tujuan pendidikan Nasional menghendaki pencapaian ketiga domain/aspek yang ada secara integral dalam rangka memperoleh lulusan/output pendidikan yang relevan dengan tujuan pendidikan nasional.

Tujuan pendidikan yang berkaitan dengan perwujudan domain-domain anak didik diupayakan melalui suatu proses pendidikan,yang kalau dibuat secara hirarkis tujuan pendidikan itu sebagai berikut:
a. Tujuan Pendidikan Nasional
b. Tujuan Institusional
c. Tujuan Kurikuler
d. Tujuan Instruksional;
1) Tujuan Instruksional Umum
2) Tujuan InstruksionalKhusus

2. Komponen Isi atau Struktur Pogram atau Materi

Komponen isi dan struktur program atau materi merupakan materi yang diprogramkan untuk mencapai tujuan pendidikan yang telah ditetapkan. Isi atau materi yang dimaksud biasanya berupa materi bidang studi, misalnya: Matematika, Bahasa Indonesia,IPA, IPS, Fiqh, Aqidah Akhlak, BahasaArab, danlain sebagainya. Bidang studi tersebut disesuaikan dengan jenis, jenjang dan jalur pendidikan yang ada, dan bidang studi tersebut biasanya telah dicantumkan atau dimuatkan dalam struktur program kurikulum suatu sekolah.

3. Komponen Media atau Sarana dan Prasarana 
Media merupakan sarana dan perantara dalam pembelajaran. Sarana dan prasarana rnerupakan alat bantu untuk memudahkan dalam mengaplikasikan isi kurikulum agar lebih mudah dimengerti oleh anak didik dalam PBM. Pemakaian media dalam PBM merupakan suatu hal yang perlu dilaksanakan oleh pendidik agar apa yang disampaikannya terhadap anak didik dapat memiliki makna dan arti penting bagi anak didik dikarenakan telah berhasil menyerap, memahami suatu materi pelajaran yang telah dipelajarinya.

Ketepatan memilih alat media merupakan suatu hal yang dituntut bagi seorang pendidik agar materi yang disampaikan pada anak didik bisa berjalan sebagaimana mestinya, dan tujuan pembelajaran dalam PBM yang diharapkan bisa tercapai dengan baik.

4. Komponen Strategi Belajar Mengajar

Dalam PBM seorang pendidik harus memahami strategi. Strategi menunjuk pada suatu pendekatan, metode dan peralatan mengajar yang diperlukan dalam pembelajaran. Strategi pembelajaran dipahami sebagai cara yang dimiliki oleh pendidik atau guru dalam PBM. Strategi punya arti yang komprehensif yang harus diupayakan untuk pengapli kasiannya oleh pendidik terhadap anak didiknya sejak dari rnempersiapkan pembelajaran sampai proses evaluasi. Dengan penggunaan srategi yang tepat, diharapkan hasil yang diperoleh dalam PBM dapat memuaskan bagi pendidik maupun anak didik, narnun penggunaanstrategi yang tepat dan akurat sangat ditentukan oleh tingkat kompetensi pendidik. Dan penggunaan strategi mengarahkan proses pembelajaran pada two ways communication.

5. Komponen Proses Berajar Mengajar

Komponenini sangat penting dalam pendidikan.Tujuan akhir dari PBM adalah diharapkan terjadinya perubahan tingkah laku anak. Komponen ini mempunyai keterkaitan erat dengan suasana belajar di ruang kelas maupun di luar kelas. Berbagai upaya pendidik untuk menumbuhkan motivasi, kreatifitas dalam belajar merupakan langkah yang tepat.

Dalam kaitannya dengan pendidik dalam menciptakan suasana pembelajaran yang kondusif agar efektifitas tercipta dalam pembelajaran, guru perlu memusatkan pada kepribadiannya dalam mengajar, menerapkan metode 
rnengajamya, memusatkan pada proses dan produknya, dan memusatkan pada kompetensinya yang relevan. Mengoptimalkan peran guru sebagai educator, motivator, manager, dan fasilitator merupakan tuntutan dalam memperlancar PBM.

6. Komponen Evaluasi atau penilaian

Untuk melihat sejauh mana keberhasilan dalam pelaksanaan kurikulum maka diperlukan evaluasi. Karena evaluasi berhubungan dengan komponen lain, maka cara penilaian ini akan menentukan tujuan kurikulum, materi/bahan, dan PBM.

Dalam mengevaluasi biasanya seseorang pendidik akan mengevaluasi anak didik dengan materi yang telah diajarkan. Ini penting karena hasil yang diperoleh anak menjadi barometer atas keberhasilan proses pembelajaran pada suatu sekolat,dan berkaitan erat dengan masa depan anak. Namun penilaian tidak hanya untuk memperlihatkan tingkat prestasi anak didik tetapi juga sebagai sumber input dalam upaya perbaikan dan pembaharuan suatu kurikulum. Penilaian dalam arti luas, dapat dilakukan tidak hanya oleh pendidik tetapi juga kalangan rnasyarakat luas dan mereka yang berwenang dalam pendidikan.

Beberapa ahli menganjurkan cara dan yang berbeda-beda dalam mengembangkan kurikulum. Ada yang menganjurkan setelah merumuskan tujuan agar disusun alat evaluasnya, kemudian diikuti bahan atau isi dan proses belajar mengajarnya. Ada pula ahli yang menganjurkan untuk melihat buku yang akan dipelajari (berpedoman Dengan buku pelajaran yang dianggap cocok), kemudian baru menentukan tujuan yang akan dicapai berdasarkan hahan tersebut, setelah itu menentukan proses belajar rnengajar dan alat evaluasinya. Dalarn praktiknya, semua aspek tersebut ditentukan tanpa urutan, dengan demikian, maka dalam proses pengembangan kurikulum akan ada proses interaksi yang mengarah pada perpaduan dan penyempurnaan.

Pengembangan kurikulum memiliki fungsi dan peranan vital dalam kegiatan pembelajaran. Secara umum, kurikulum memiliki fungsi sebagai pedoman. Secara spesifik, terdapat berbagai fungsi pengembangan kurikulum sebagaian dapat disebutkan di bawah ini:

a. Fungsi kurikulum dalam rangka pencapaian tujuan pendidikan. Kurikulum pada suatu lembaga pendidikan merupakan alat atau usaha dalam rnencapai tujuan-tujuan pendidikan yang 
diharapkan oleh sekolah tertentu yang dianggap tepat dan penting untuk dicapai, sehingga salah satu langkah yang perlu dilakukan adalah meninjau, kembali tujuan yang selama ini digunakan oleh sekolah bersangkutan.

b. Fungsi kurikulum bagi anak didik. Keberadaan kurikulum sebagai organisasi belajar yang tersusun merupakan suatu persiapan bagi anak didik. Anak didik diharapkan mendapat sejumlah pengalaman baru yang kemudian hari diharapkan dapat dikembangkan seirama dengan perkembangan anak, agar dapat mempersiapkan bekal kehidupannya di masa mendatang. Dalam pendidikan Islam, khususnya di Madrasah Ibtidaiyah, pendidikan harus diorientasikan kepada kepentingan peserta didik, dan perlu diberi bekal untuk hidup pada zamannya kelak. Dalam sebuah Hadist Nabi disebutkan "didiklah anak-anakrnu, karena mereka diciptakan untuk menghadapi zaman yang lain dari zamanmu".

c. Fungsi kurikulum bagi pendidik. Kurikulum bagi bendidik berfungsi sebagai: 1) pedoman kerja dalam menyusun dan mengorganisir pengalaman belajar para unak didik, 2) pedoman untuk mengadakan evaluasi terhadap perkernbangan anak didik dalam rangka menyerap sejumlah pengalaman yang diberikan. menurut Langeveld ada lima komponen yang berinteraksi secara akrif dalam proses pendidikan, yaitu: 1) komponen tujuan pendidikan, 2) komponen terdidik, 3) komponen alat pendidikan, 4) komponen pendidik,5) komponen lingkungan pendidikan.

d. Fungsi kurikulum bagi kepala sekolah dan Pembina sekolah. Kurikulum, bagi kepala sekolah dan para pembina memiliki fungsi sebagai: l) pedoman dalam mengadakan fungsi supervise yakni memperbaiki situasi belajar, 2) pedoman dalam melaksanakan fungsi supervisi dalam menciptakan situasi belajar, 3) pedoman dalam melaksanakan fungsi supervisi dalam memberikan bantuan pada guru, 4) pedoman untuk mengembangkan kurikulum pada masa mendatang, 5) pedoman untuk mengadakan evaluasi atas kemajuan pembelajaran.

e. Fungsi kurikulum bagi orang tua anak didik. Kurikulum, bagi orang tua, mempunyai fungsi agar orang tua dapat berpartisipasi membantu usaha sekolah dalam memajukan putra-putrinya.

f. Fungsi sekolah pada tingkat diatasnya, fungsi tersebut adalah 
fungsi pemeliharaan keseimbangan proses pendidikan dan fungsi penyiapan tenaga baru.

g. Fungsi bagi masyarakat dan pemakai lulusan sekolah. Dengan mengetahui kurikulum pada suatu sekolah, masyarakat sebagai pemakai lulusan, dapat ikut memberikan kontribusi dalam memperlancar pelaksanaan program pendidikan dan ikut memberikan kritik dan saran yang konstruktif demi penyempurnaan program pendidikan di sekolah.

Menurut Alexander Inglis dalam bukunya principle of secondary education, kurikulum memiliki fungsi: the adjusfine, of adaptive function/fungsi penyesuaian, the integrative function/fungsi pengintegrasian; the diferentiating function/fungsi pembeda, the propaedeutic function/fungsi persiapan, the selective function/fungsi pemilihan, the diagnostic functioni/ fungsi diagnostik.

Sedangkan peranan dari pengembangan kurikulum adalah peranan konservatif, peranan kritis dan evaluatif, peranan kreatif. Kurikulum dikatakan berperan konservatif karena menstransmisikan dan menafsirkan warisan sosial kepada anak didik atau generasi muda. Kurikulum berperan kritis dan evaluatif karena kurikulum sekolah tidak hanya mewariskan kebudayaan yang ada, melainkan juga menilai, memilih unsur-ulsur kebudayaan yang akan diwariskan (juga sebagai alat untuk mengevaluasi kebudayaan yang ada. Sedangkan peran kreatif adalah karena kurikulum disini melakukan kegiatan-kegiatan kreatif dan konstruktif, dalarn arti menciptakan dan menyusun sesuatu yang baru sesuai dengan kebutuhan masa sekarang dan masa yang akan datang dalam masyarakat.

Dalam mengembangkan kurikulum banyak hal yang harus diperhatikan dan diperhatikan sebelum mengambil keputusan. Apapun jenis kurikulum memerlukan asas-asas landasan/dasar yang harus dipegang dan diperhatikan secara ketat. Pengembangan kurikulum antar satu negara dengan Negara yang lain pasti memiliki perbedaan-perbedaan, namun juga memiliki kesamaankesamaan juga. Adapun asas-asas yang dijadikan landasan dalam mengembangkan kurikulum Madrasah Ibtidaiyah adalah:

a. Asas filosofis.

Seorang pengembang kurikulum, dalam mengembangkan kurikulum hendaknya tidak hanya menonjolkan filsafah pribadinya, namun perlu mempertimbangkan filsafat-filsafat 
lain, antara lain filsafat Negara, filsafat lembaga pendidikan dan staff pengajar atau pendidik.

b. Asas sosiologis.

Asas ini memiliki peran penting dalam mengembangkan kurikulum pendidikan pada masyarakat dan bangsa apa saja di muka bumi ini. Suatu kurikulum, pada prinsipnya mencerminkan keinginan, cita-cita tertentu dan kebutuhan masyarakat. Sedangkan dari sudut pandang sosiologis, sistem pendidikan drn lembaga-lembaga pendidikan, dapat dilihat sebagai bahan yang memiliki beragam fungsi bagi kepentingan masyarakat, yakni: 1) Mengadakan revisi dan perubahan sosial, 2) Mempertahankan kebebasan akademis dan kebebasan melaksanakan penelitian ilmiah, 3) mendukung dan turut memberi kontribusi terhadap pembangunan, 4) menyampaikan kebudayaan dan nilai-nilai tradisional, 5) mengeksploitasi orang banyak demi kesejahteraan golongan elit, dan sebagainya.

c. Asas psikologis.

Kontribusi psikologi terhadap studi kurikulum memiliki dua hal. Pertama, model konseptual dan informasi akan membantu perencanaan pendidikan, kedua, berisikan metodologimetodologi yang dapat diadaptasikan untuk penelitian pendidikan.

Selain asas yang harus diperhatikan dalam pengembangan kurikulum, ada juga beberapa prinsip yang perlu mendapatkan perhatian penting dalam rangka pengembangan kurikulum. Prinsip-prinsip tersebut adalah:

a. Prinsip relevansi

Prinsip ini berkaitan dengan kedekatan hubungan dengan apa yang terjadi. Pendidikan dikatakan relevan bila hasil yang diperoleh akan berguna bagi kehidupan seseorang. Menurut Soetopo dan Soemanto serta menurut Soebandijah, prinsip relevansi sebagai berikut: relevansi pendidikan dengan lingkungan anak didik, relevansi pendidikan dengan kehidupan sekarang dan kehidupan yang akan datang, dan relevansi pendidikan dengan dunia kerja, serta relevansi pendidikan dengan ilmu pengetahuan.

b. Prinsip efektifitas

Prinsip ini berkaitan dengan sejauh mana perencanaan kurikulum dapat dicapai sesuai dengan keinginan yang telah 
ditentukan. Dalam pendidikan, efektifitas dapat dilihat dari dua sisi: l) efektifitas mengajar pendidik berkaitan dengan sejauhmana kegiatan belajar mengajar yang telah direncanakan dapat dilaksanakan dengan baik; 2) efektifitas belajar anak didik berkaitan dengan sejauhmana tujuan-tujuan pelajaran yang diinginkan telah dapat dicapai melalui KBM yang telah dilaksanakan.

c. Prinsip efisiensi

Terciptanya efisiensi PBM, apabila usaha, biaya, dan tenaga yang digunakan untuk menyelesaikan program pengajaran tersebut sangat optimal dan hasilnya seoptimal mungkin, dengan pertimbangan yang rasional dan wajar.

d. Prinsip kesinambungan kontinuitas

Prinsip kesinambungan dalam pengembangan kurikulum menunjukkan saling keterkaitan antara tingkat pendidikan, jenis progam pendidikan dan bidang studi.

e. Prinsip fleksibilitas

Fleksibilitas maksudnya tidak kaku, ada semacam ruang gerak yang memberikan kebebasan dalam bertindak. Fleksibilitas di dalam kurikulum ada dua macam yaitu, fleksibilitas dalam memilih program pendidikan dan fleksibilitas dalam pengembangan program pengajaran.

f. Prinsip berorientasipada tujuan

Ini berarti bahwa sebelum bahan ditentukan, langkah utama yang harus dilakukan oleh pendidik adalah menentukan tujuan terlebih dulu. Hal ini perlu agar semua jam dan aktifitas pembelajaran yang dilaksanakan oleh pendidik dan anak didik diharapkan mengarah pada tercapainya tujuan pendidikan yang telah ditetapkan. Karena dengan penentuan tujuan dalarn kurikulum, maka dapat ditentukan pula metode mengajar, alat pelajaran,dan evaluasinya.

g. Prinsip dan model pengembangan kurikulum.

Prinsip ini bermaksud bahwa pengembangan kurikulurn secara bertahap dan terus menerus. Caranya dengan mengembangkan pelaksanaan dari hasil-hasil yang telah dicapai untuk melakukan perbaikan, pemantapan dan pengembangan lebih lanjut.

h. Prinsip pendidikan seumur hidup

Prinsip ini mengandung implikasi bahwa sekolah tidak saja memberi pengetahuan dan ketrampilan yang diperlukan pada 
saat peserta didik tamat dari sekolah, namun juga memberikan bekal kemampuan untuk dapat menumbuhkembangkan dirinya sendiri di luar sekolah dan berjalan secara terus menerus sepanjang hayatnya.

Selain harus memperhatikan berbagai prinsip dalam pengembangan kurikulum, para pengembang/developers biasanya menggunakan pendekatan tertentu dalam mengembangkan kurikulum. Pendekatan sendiri maksudnya adalah cara kerja dengan menerapkan strategi dan metode yang tepat dengan mengikuti langkah-langkah pengembangan yang sistematis agar memperoleh kurikulum yang lebih baik. Adapun pendekatanpandekatan yang dikembangkan oleh pengembang kurikulum adalah sebagai berikut:

a. Pendekatan bidang studi.

Pendekatan ini juga disebut pendekatan subjek atau disiplin ilmu. Pendekaian ini menggunakan bidang studi sebagai dasar dalam organisasi kurikulum. Misalnya IPS, Matematika, Sains, Sejarah, Geografi, dan lain-lain. Hal ini sebagaimana dapat dilihat dan didapati dalam sistem pendidikan di Indonesia pada semua sekolah dan perguruan tinggi. Prioritas pendekatan ini pada sifat perencanaan program serta pengutamaan pada penguasaan bahan dan proses dalam disiplin ilmu tertentu.

b. Pendekatan berorientasi pada tujuan. Pendekatan ini menempatkan rumusan tujuan yang hendak dicapai dalam posisi sentral, sebab tujuan adalah pemberi arah dalam pelaksanaan PBM.

c. Pendekatan dengan pola organisasi bahan.

Pendekatan ini dapat dilihat dari pola pendekatan: subject matter curriculum, correloted curriculum, dan integrated curriculum.

1) Pendekatan dengan pola subject matter curriculum menekankan pada mata pelajaran-mata pelajaran secara terpisah-pisah. Misalnya Sejarah Ilmu Bumi, Biologi, dan sebagainya. Mata pelajaran ini tidak berhubungan satu sama lain.

2) Pendekatan dengan pola correlated curriculum menekankan pada

Pengelompokan beberapa bahan pelajaran yang seling berhubungan. Misalnya bidang studi IPA, IPS, dan sebagainya. Pendekatan ini dapat dilihat dari berbagai aspek 
yaitu: pendekatan structural, pendekatan fungsional, dan pendekatan tempat atau

3) Pendekatan dengan pola integrated curriculum. Pendekatan ini didasarkan pada keseluruhan hal yang mempunyai arti tertentu. Misalnya pembahasan tentang pohon, dalam hal ini, pembahasannya tidak hanya melalui mata pelajaran yang terpisah-pisah, namun harus dijalin suatu keutuhan yang meniadakan batas tertentu dari masing-masing bahan pelajaran.

d. Pendekatan rekonstruksionisme.

Pendekatan ini juga disebut rekonstruksi sosial karena memfokuskan pada masalah-masalah penting yang dihadapi masyarakat. Seperti masalah kriminalitas, banjir,kepadatan penduduk dan sebagainya. Dalam hal ini terdapat dua kelompok yang sangat berbeda pandangan terhadap kurikulum, yaitu: 1) Rekonstruksionalisme konservatif, pendekatan ini berupaya meningkatkan mutu kehidupan dengan mencarisolusi masalahmasalah yang paling mendesak dalam masyarakat. 2) rekonstruksionalisme radikal, Pendekatan ini menggunakan pendidikan untuk merombak tata sosial yang ada dan membangun struktur sosial baru.

e. Pendekatan humanistic.

Kurikulum ini berpusat pada anak/student centered, dan mengutamakan perkembangan aktif anak sebagai bagian integral dari proses belajar. Prioritasnya adalah pengalaman belajar yang diarahkan terhadap tanggapan minat Kebutuhan dan kemampuan anak.

f. Pendekatan akuntabilitas.

Accountability atau pertanggungjawaban lembaga pendidikan tentang pelaksanaan tugasnya kepada masyarakat merupakan pengaruh yang penting dalam dunia pendidikan. Karena suatu sistem yang accountable menentukan standar dan tujuan spesifik yang jelas dan mengukur efektifitas berdasarkan taraf keberhasilan siswa dalam mencapai standar itu.

g. Pendekatan pembangunan nasional.

Pendidikan dengan pendekatan ini mengemban tiga tugas pokok yaitu: pendidikan kewarganegaraan, pendidikan sebagai alat pembangunan nasional, dan pendidikan ketrampilan khusus bagi kehidupan sehari hari. 
h. Pendekatan kompetensi.

Kornpetensi disini bermakna kemampuan melakukan sesuatu yang diperoleh melalui pendidikan dan latihan mulai dari yang sederhana sampai dengan yang komplek. Dalam hubungannya dengan tenaga profesional kependidikan, kompetensi menunjuk kepada perbuatan, kinerja, unjuk kerja/performance yang bersifat rasional dalam memenuhi spesifikasi tertenru di dalam rugas-tugas kependidikan.

Selain hal-hal yang telah disebutkan di atas,ada hal lain yang perlu dipertimbangkan dalam pengembangan kurikulum, yaitu faktor-faktor yang mempengaruhi dalam mengembangkan kurikulum' Pengembangan kurikulum sangat dipengaruhi oleh beberapa fautor, diantaranya adalah faktor perguruan tinggi, faktor kajian keilmuan, faktor situasidan kondisi, faktor masyarakat faktor sistem nilai, dan faktor-faktor lain. 


\section{Penutup}

Pengembangan kurikulum merupakan usaha yang sangat komplek dengan banyak alternative sehingga harus mengadakan pilihan dan keputusan. Kurikulum dikatakan sebagai "a matterof choice" soal pilihan. Pada tataran perencanaan dan pengembangan, kurikulum masih merupakan suatu yang ideal, sesuatu yang diharapkan atau dicita-citakan akan dapat direalisasikan dan merupakan ku rikulum yang nyata atau real kurikulum.

Dalam struktur pengembangan kurikulum, melibatkan berbaga komponen atau unsur. Setiap komponen memerlukan pengembangan yang tepat dan serius, karena kesatuan, keterkaitan, dan keterpaduan antara berbaga komponen dalam kurikulum merupakanp roses untuk pencapaian tujuan pendidikan. 


\section{REFERENSI}

Abdullah Idi. (1999). PengemhanganKurikulum: teori dan praktik. Jakarta: Gaya Media Pratama

Mulyasa. (2002). Kurikulum Berbasis Kompetensi. Bandung: Remaja Rosdakarya

Mulyasa. (2006). Kurikulum Tingkat Satuan Pendidikan. Bandung: Remaja Rosdakarya

Muslam. (2003). Pengembangan Kurikulum: Teoritis \& Praktis. Semarang: PKPI2

Muslam.(2006). Pengembangan Kurikulum MI/PAI SD: teoritis \& praktis. Semarang: PKPI2

Nana Syaodih Sukmadinata. (1997). Pengembangan Kurikulum:Teori dan Pratik. Bandung: Remaja Rosdakarya 